\title{
Prospective English Teachers' Knowledge on Mind Mapping
}

\author{
Natalia Christiani ${ }^{1}$ \\ Novalita Fransisca Tungka ${ }^{2}$ \\ Romauli Nainggolan ${ }^{1}$ \\ ${ }^{1}$ Universitas Ciputra Surabaya, \\ CitraLand CBD Boulevard, Made, Kec. Sambikerep, \\ Kota SBY, Jawa Timur 60219, Indonesia \\ ${ }^{2}$ Universitas Sintuwu Maroso Poso - Poso, \\ Jl. Pulau Timor, Gebang Rejo, Poso Kota Sel., \\ Kabupaten Poso, Sulawesi Tengah 94612, \\ Indonesia
}

DOI: https://doi.org/10.36941/jesr-2022-0042

\section{Abstract}

The purpose of this research was investigating prospective English teachers' knowledge on mind mapping by using a questionnaire. There were 142 respondents from various semesters of their study in English Department, Faculty of Teacher Training and Education, in three cities in Indonesia, i.e., Medan, Sidoarjo, and Poso. The questionnaire consisted of 7 items of close and open-ended questions that asked about the prospective English teachers' knowledge on mind mapping and its usage. Questionnaire was analyzed using descriptive quantitative research method. Result showed that almost $50 \%$ of the prospective English teachers have known about mind mapping. This bases result can be suggested to extend by analyzing its usage in another skills of English learned by these prospective teachers.

Keywords: Prospective English teachers, knowledge, mind mapping, Indonesia

\section{Introduction}

Consisted of more than 270 million people, Indonesia needs qualified teachers to educate the generations of this world. The words of 'qualified teachers' reflect to the characteristics of good teachers who have competencies, attitudes, and characteristics at all levels of education that bring through learners to reach desired learning outcomes by solving problems, thinking critically, working collaboratively, and become potential citizens (Borg, 2006; Hunt, 2009; Kulekci, 2018). This happens to the English language educators. They are identified as the main figures in the language learning process that affect bases to learners' progress, are eager to teach, understand the learners' needs and do their best to carry out their learners' learning experiences (Cheung, 2006; Arnon \& Reichel, 2007; Korkmaz \& Yavuz, 2011). 
Recent years, institutions and/or higher educations which are specifically focus and have objectives in training learner-centered teaching methods and techniques encourage their learners to be developed based on the approach of constructivism. The teachers should be able to lead their learners to maximize their brains, their prior knowledge, and their ways of thinking on a given task or assignment. In constructivism, Kim (2001) stated that the learners are the constructers. Meaning that throughout their perspectives, they design and transfer the language learning they produce from their nature of thinking and enrich it by using their ideas also tools in a variety of ways. According to Sluijsnmans and Strijbos (2010), the learners then implement intended interaction by emphasizing various sources and materials that are available to build the attractively learning environment which are guided and supported by the teachers. The main point of this constructivism is that the learners are the constructers who are trained to active, able to create ideas, and share their ideas in an effective learning process environment (Marlowe \& Page, 1998; Sluijsmans \& Strijbos, 2010 in Durmus, 2016).

Based on the previous statement, the researchers see there are still many opportunities to apply the constructivist method in nowadays teaching and learning process. In the Psychology learning theory, this approach explains how people might acquire knowledge and learn (Sarita, 2017). Therefore, it is suggested to directly implement it to the learners so then they can construct knowledge and value from their experiences for themselves by exploring the learning environment and engaging their critical thinking and problem solving (Dev, 2016). Thus, what teachers prepare and do should establish the learners' capability and performance through drills and practices. Teachers' guidance in the learner-centered pedagogy activities opens wide occasion to the learners' experiences, their opinions, and their active contributions in responding, symbolizing, reflecting, and reviewing the tasks given as selves-achievement. According to Dev (2016), a self-made achievement can be used as a measurement to the learners' academic performance toward their prior knowledge. All these views point the researchers to a tool which can be also a technique that activate the learners themselves to effectively use their brains and then practice them to make efforts on the academic performance they produce. The tool or technique or strategy is by then called mind mapping.

The present research motivates the researcher to investigate the knowledge of the prospective English teachers who are still being trained by the programs of becoming effective teachers on mind mapping. How far the future teachers understand and use mind mapping as a technique in their teaching and learning process plan be described in the result of this research. The expected result could give contribution to other researchers that analyze about the usage of mind mapping especially in the educational field as the implementation of constructivism approach.

\subsection{Theoretical Framework}

To having qualified English language teachers, Indonesia Government concerns in establishing as many Faculties of Teacher Training and Education (FKIP) as possible particularly English Department to produce best prospective English teachers. For its citizen to be able to compete in global standards, it is inevitable for the government to step in on the matter as to support and improve the quality of English language learning. According to Witcher et al., (2001 in Kulecki, 2018), there were six categories summed up of 125 characteristics of best prospective English teachers possessed:

- $79.5 \%$ is being student-centered

- $40.2 \%$ is willingness to teach

- $38.8 \%$ is ethicalness

- $33.3 \%$ is effective classroom and behavior management

- $32.4 \%$ is teaching methodology

- $31.5 \%$ is knowledge of subject matter

Those categories are shortened by The American of School Administrators (AASA) that 
basically, the ideal prospective English teachers are divided into two main categories: techniques of management and instructional and personal characteristics (Demmon-Berger, 1986). As good managers, they must use the instruction techniques systematically, be able to change teaching strategies, believe in the learners' efficacy, adjust teaching to the learners needs, create a comfortable interaction with others, could spend time with the learners outside of class meeting, and are flexible and so imaginative (Kulecki, 2018). As Porter and Brophy (1988 in Elizabeth et al., 2008) notified that the best prospective teachers organized and presented content knowledge for the learning of learners. Related to the statement, these teachers should also master these skills:

- Planning

- Assessment and evaluation

- Designing assignments

- Developing good work-study habits

- Using motivating techniques

- Questioning techniques

- Oral and written communication

- Using instructional materials resourcefully

- Recognition of and provision for individual differences

- Speech, articulation, and voice quality.

As stated above, there are several definitions and skills must be had by best prospective English teachers. Being effective or successful or best prospective English teachers face and accomplish the skills in a dynamic process which implies different meanings to different people. Institutions give supports in training and facilitating the teachers to practice and perform those essentials skills sincerely and committed. Therefore, based on three categories mentioned: highly expectations to conduct learner-centered learning, developing good work-study habits, and using motivating techniques, the research carries out concerning a technique of studying and learning which can motivate learners' both brains active and synergize; thus, they can be motivated, improved, and be discipline-autonomous learners. For providing this technique, it is hoped for English educators and learners whether they have it as a first or second language, to improve the level of education and learning in many various aspects. The technique is called mind mapping.

Buzan (1974) discovered mind mapping both as a tool and a technique to boost humans' brains. There are two parts of humans' brains, left and right brains. Most of the time, humans use to activate one brain only to study, work, think, and elaborate any tasks or assignments given. This makes them as linier users. Based on the illustration inside of human's brains, the laws of mind mapping pioneered by Buzan (1974) are not far from the forms of brain's neutrons. From their shapes, mind mapping is created. Neutrons consist of branches that are made from a central point then spread into branches; however, the branches are started from the thickest branches and continued to thin branches, and until the thinnest ones. These neutrons work so amazingly. They are also formed in curves not straight branches. Thus, Buzan (1974) had a thought of how humans' brains can be trained as the description using mind mapping, as a representative idea, image, picture, and or illustration which then can enrich and improve humans' skills.

Mind mapping is created to synergize both brains and create more and more creative also active personalities in life, particularly in learners' skills to develop their literacy skills (Buzan, 2012; Christiani, 2014). As a learning tool to enriching learners' literacy skills, mind mapping can help the processes of teaching and learning. They are called as schemata process and as outlining one. Schemata process reflects the activity in reading comprehension; whilst outlining process describes the activity in writing or rewriting. Those processes are done as one process of learning which mind mapping becomes a medium to develop learners improving their literacy skills, i.e., reading and writing skills. In reading, mind mapping utilizes learners' minds for retention, recalling, integration, assimilation, recognition, and communication processes (Buzan, 1974). All these merits help learners to focus on their reading and make their perceptions up towards the information. In writing, mind 
mapping can encourage the learners to write or rewrite. Therefore, the method can assist in education of linguistics and languages in regards to in depth learning and crafting a creation of writing or visual.

According to Krashen (1984), addressing the correlation of reading-writing learning progress, starting by reading certain passages can help to acquire writing skills. With trained reading comprehension, ideas, insights, and information can easily be attained to improve the learner's writing skill. Utilizing mind mapping can act as a support of visual that act as a second role that can improve the learner's writing skill (Chan, 2004). As the visual, mind mapping gives the brain a picture of the topic hence the maker can organize their ideas better followed with planning a structure on the topic itself to produce a comprehensive paper.

Mind mapping in concept highlights the use of keywords, visual images or symbols, curved branches, and colorful branches. The presentation of mind mapping is using landscape paper and starts from the center of the paper that shows the main topic. The main topic located in the center is known as Basic Order Ideas (BOIs). Furthermore, BOIs is determined through specifying objectives and information; answering key questions such as who, what, when, where, why, how, and which; also reviewing the reading material headings. Describing the BOIs through branches starts from the right and goes clockwise. The branches include keywords, images, symbols, and or codes presented throughout the lines and indicate the main idea of paragraphs, chapter headings, or chapters. Continued with more branches that point out the supporting ideas. Later, ideas displayed in the mind mapping form are examined to find correlation, similarities, and linkages throughout the whole structure (Christiani, 2017). The steps to construct a mind mapping are as follows:

1. Note down the main topic of reading material or writing in the center of a blank horizontal paper. An image can be used as a visualizer.

2. Stretch a thick branch from the main topic starting from the right side. The branch can be more than one drawn with different colors.

3. Draw the second branch from the main branch by applying the same color as the main branch. This branch is thinner than the main branch.

4. Note down the keywords on the branch and add supporting visuals such as pictures or symbols.

5. Proceed until a specified point that the main topic is described. The branches must be drawn with different colors that indicates the different specifications and from the thickest to the thinnest lines. Each sub-topic will also be supported with visualization through pictures or symbols.

By implementing the mind mapping method combined with reading-writing learning strategy can further improve literacy strategy, this is named reading-to-mind mapping-to-writing method ( $\mathrm{R}$ MM-W) (Christiani, 2017). This research aims to investigate the knowledge of the prospective teachers of English on mind mapping. This inquiry is significant because the prospective teachers will become real teachers in teaching English and their knowledge are essential in forming their teaching method, cognition, and practices. In regards to this, when prospective teachers are able to implement the essential aspect, the quality of English language education can be improved for those who have it as a second language. In regards to results of conducting education by utilizing mind mapping method, an earlier research has proven that the use of mind mapping is highly effective for the learners across genders by showing the difference of their test result from using the traditional way of teaching and with the usage of mind mapping throughout the chapter study, hence it is without a doubt with full understanding the result can improve exponentially as learners and prospective teachers will have an assistant tool in deepening their education in the matter of language studies and development (Parikh, 2016). 


\section{Methodology}

\subsection{Research Design}

This study utilizes descriptive quantitative research method to emphasize the use of numerical data that will be analyzed to construct a conclusion. Descriptive method focuses on finding variables, without looking at the number of variables, by eliminating comparison and connection with other variables (Muldyagin, 2018). By utilizing the finding of variables, the descriptive report is able to provide a clear, detailed, and measureable interpretation regarding the case being discussed (Grimes, D. A., Schulz, K. F., 2002). According to Watson (2015), quantitative research embodies a series of methods involving inquiries using statistical or numerical data.

\subsection{Research Purpose}

The output of this research might supply useful view for educators, teacher in-training, and learners in English language educations and act as a preliminary information for analysis in future research regarding this concept by providing a start of the topic of mind mapping for educators. This study aims to provide a new effective method of learning that can (1) conduct learner-centered learning, (2) develop good work-study habits, and (3) use motivating techniques to improve the English language learning system. Through this method provided based on the research, it hoped for improving the education method, individually and/or in a class environment, of English language learning system for learners that have this language as a second language to their native language wherever they may be in the world.

\subsection{Sample and Data Collection}

This study involved 142 English language educators and educators' in-training of 3 universities in Indonesia from 3 different cities, i.e., Medan, Sidoarjo, and Poso. There were 38 respondents from Medan, 57 respondents from Sidoarjo, and 47 respondents from Poso. They were elected as the samples of this study on the outset of introducing a teaching and learning method that are learnercentered, highlighting good work-study habit, and motivating for English language educators and learners. Hence, these future English educators can practice the mind mapping technique since they are learners which then to be applied during their teaching days. The respondents are learners and educators involved in English language studies in the range of 2 nd - 3rd year of their study period.

This research applies a survey for researcher to attain qualitative data that will be presented in descriptive quantitative data to assess the understanding of English language educator in training on the concept of mind mapping as a learning tool to increase self-regulated learning. The survey consisted of 7 open-ended questions that are then processed and presented using a descriptive quantitative way in the form of graph and pie chart to present categories in which the respondents' answers in the survey.

\section{Result and Discussion}

From the survey instrument, respondents from the chosen universities have answered 7 questions to measure their knowledge about mind mapping. Each of their answers is measured through data triangulation and processed based on the quality of their answers, which then being presented in a graphic to further visualize the result of the process. As the questions are open ended, participants are able to give their free ideas and thoughts regarding the question. The results are presented through a set of graphs for each question as follows: 


\subsection{Awareness of mind mapping}

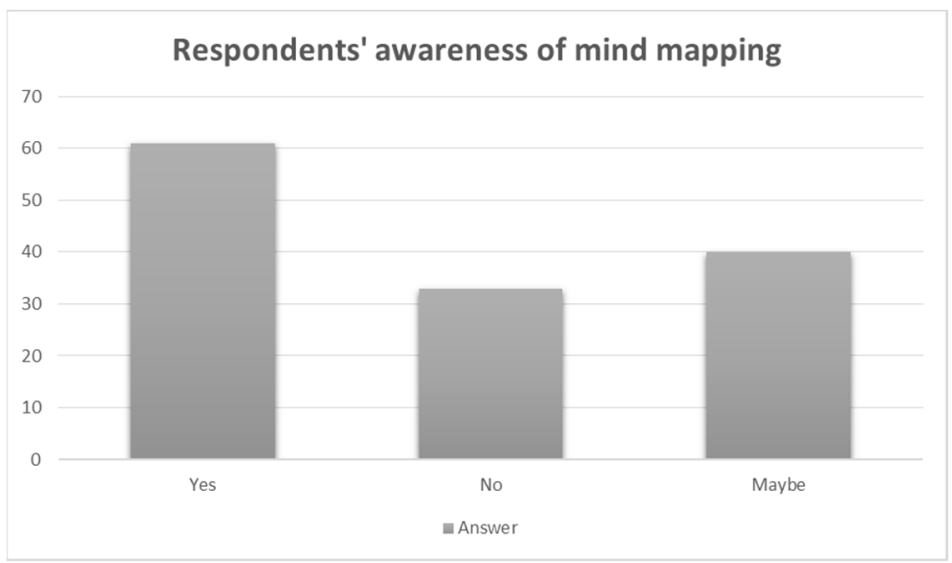

Figure 1: The respondents' awareness on mind mapping

Figure 1 shows that 62 out of 142 of our respondents are aware of the existence of mind mapping, 40 people are not sure of their knowledge, and around 33 respondents have only heard the term. It is found that there are 7 respondents do not fulfill the statement. For Indonesian English prospective teachers in their days of advance learning and training, there is little chance for them to know a common method such as mind mapping, but the result of our findings determines that shows the majority of the respondents to be either unsure or does not know the tool at all in the slightest. This further highlights the importance of preaching of mind mapping as a tool to improve the English language learning system, especially in writing. By the least to have them be aware of the existence of the tools which then leads to their understanding of its usage and how to utilize it for their field of study in order to improve their ability regarding their method of teaching.

\subsection{Times to use mind mapping}

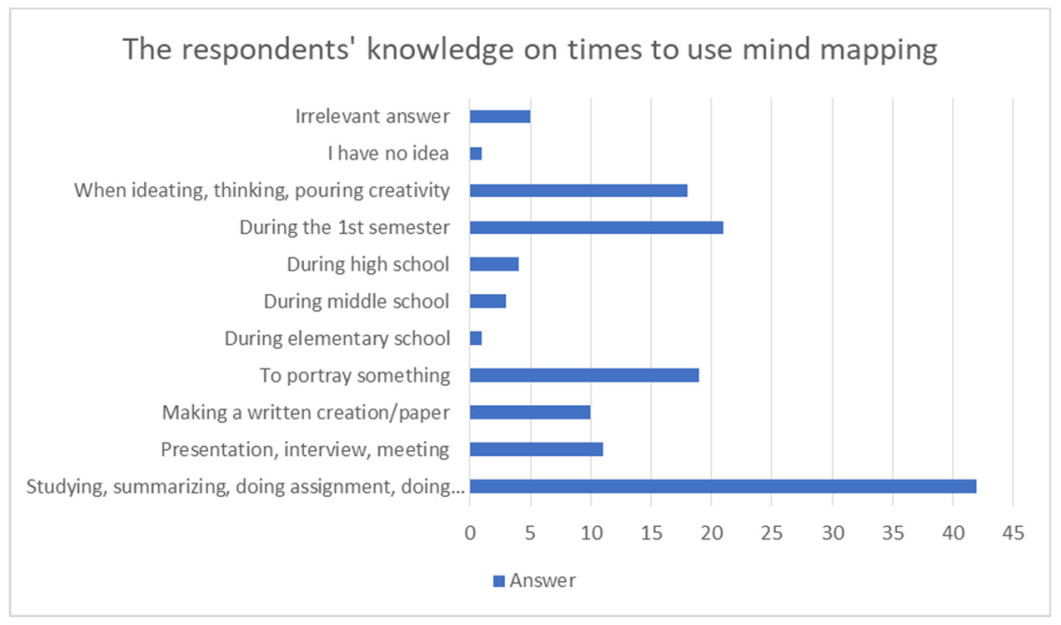

Figure 2: The respondents' knowledge on times to use mind mapping 
The figure above shows the respondents' comprehension on mind mapping through their own knowledge of times to use this tool. As it is an open-ended question, respondents answer with their own words and those answers are being classified into the few categories shown in the graph above. Most of our respondents express their answers through situations that they feel the need to use mind mapping, while few other answers based on timeline of the last time, they have used it. There are 42 respondents state that mind mapping is used to study, to summarize, to reread before examination, to make assignments, and to do research. Another higher answer, 21 respondents, say that mind mapping can be used to think some new ideas and creativity.

Though contradicting their possible previous statements, it is speculated that the respondents that answer of their nescience regarding the topic have only heard of the topic and/or thought the topic was only taught during the basic level of education in Indonesian curriculum, i.e., elementary school, middle school, and high school. It is highly appreciated as well because the majority of the respondents have mostly the same view to see mind mapping as a tool to be used in education especially in terms of individual studies that requires self-focus which supported the creation of learner-centered learning induced in creative ideas throughout the process.

\subsection{The principles of mind mapping}

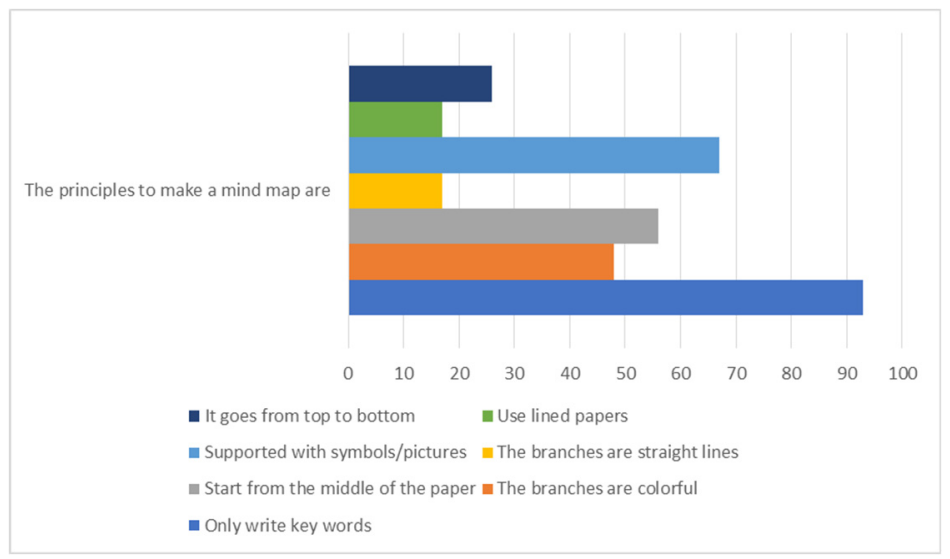

Figure 3: The respondents' thoughts on how to create mind mapping

The graph shown in Figure 3 shows how respondents think the mind mapping is constructed. The results reflecting their own knowledge regarding mind mapping as the survey are given to measure their understanding of mind mapping. This shows around 93 respondents answer that in mind mapping, they just write the keywords. They also are able to choose the correct answers of the principles in making mind mapping, such as supported by symbols or picture (67 respondents), started from the central of the paper or BOIs ( 56 respondents), and has colorful branches ( 48 respondents).

Despite their previous answers regarding their knowledge of mind mapping, the respondents' majority have shown their familiarity of how a mind mapping should be constructed. Though it can be seen from the results, there are some respondents who answered incorrectly, on two factors regarding mind mapping, and since this question allows the participants to choose multiple answers, it can be assumed that 17 respondents guessed incorrectly and to be proven to have little to none of knowledge regarding mind mapping let alone use it. For mind mapping to be effective, the presentation must be able to convey keywords and be enforced using colors, images, and/or symbols to further amplify the clarity of the topic and key words (Biktimirov, E. N., \& Nilson, L. B., 2006). 


\subsection{The use of mind mapping}

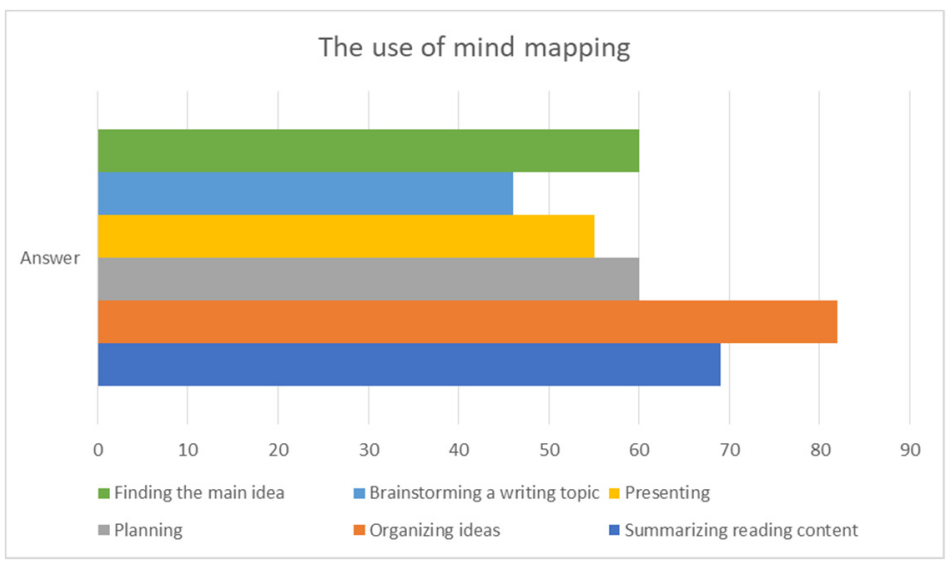

Figure 4: The use of mind mapping

Figure 4 shows most of the respondents use or will use mind mapping as a tool to organize ideas, followed with its use as a support in summarizing reading contents, then respondents also agree that mind mapping can be used to help in planning and finding the main idea of a content. It seems that by this point the respondent have already form an understanding of the form of mind mapping and they are able to visualize the way to use the tool regarding their daily task in the English education major. The prospective teachers in the language field are expected to have endless ideas that are creative and visionary, to better manage the various ideas, a tool is deemed needed by them for that reason. It is notable that through the simple content of mind mapping, prospective teachers and learners will be able to grasp a concept of a reading easily through the tool as it is seem as a tool to help on summarizing by the respondents. From the top two answers, the respondents then agree for the tool to be an assistant for them in making a new writing in a sense of helping them plan and construct a type of main idea. In addition, most of the respondents know the advantages of using mind mapping: to organize ideas (82 respondents), to summarize a reading passage (69 respondents), to plan something and to find a main idea (each 6o respondents), to present something (55 respondents), and 46 of them answer that mind mapping help them to brainstorm a topic.

\subsection{Users of mind mapping}

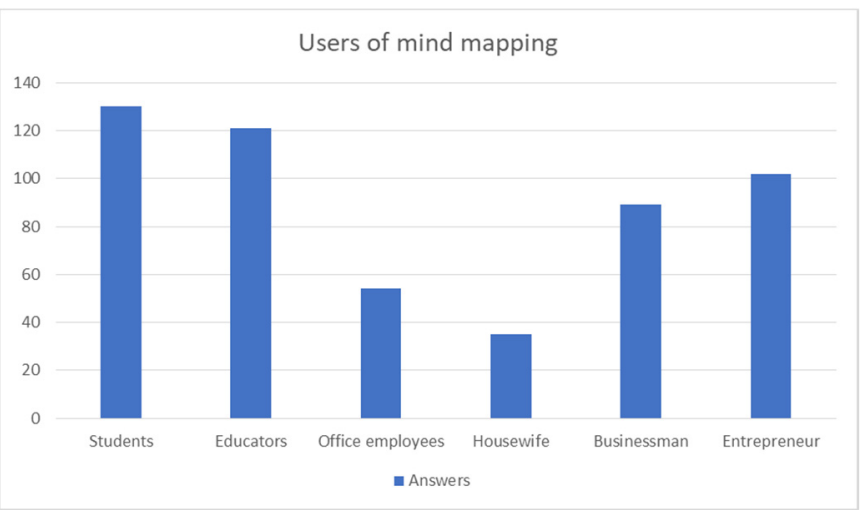

Figure 5: Users of mind mapping 
The graph in Figure 5 indicates the respondents' opinion on the actors that are using mind mapping in their field of focus. The most agreed on answer focuses on the field of education in which the respondents think that learners use this tool more often as they are conducting their studies (130 respondents), then educators as the next step of the learners that use the tool. There are 121 respondents choose it. Followed by entrepreneurs (102 respondents) in the field of business which requires constant innovation and brainstorming to develop competitive advantage in their business. This highly indicates the comprehension of the respondents' regarding the effective use of mind mapping in the field of education where it is expected for not only educators but mainly learners to actively participate in pouring out ideas and have a better comprehension skill in order to milk out the most out of the insights given in a class setting or other form of study given by the educators and mentors.

\subsection{Criteria of component in mind mapping}

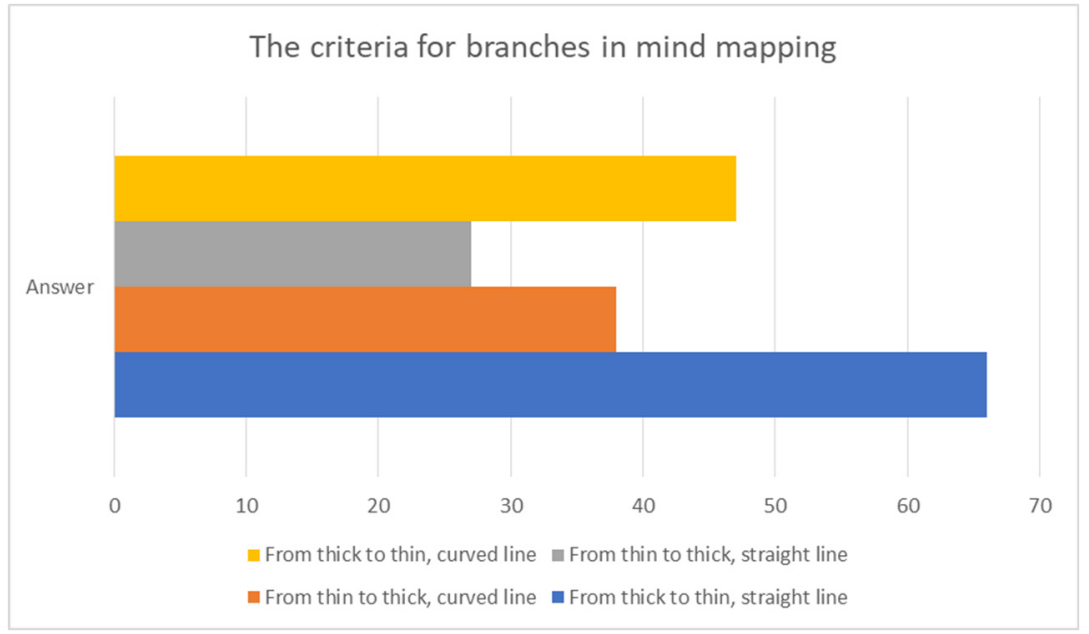

Figure 6: The criteria of branches in mind mapping

The figure above presents the respondents' thoughts on the way branches are drawn in mind mapping. The criteria listed as answers that the respondents can pick are (1) From thick to thin, curved line; (2) From thin to thick, straight line; (3) From thin to thick, curved line; (4) From thick to thin, straight line. Most respondents pick the (4) criteria which is partially correct. Then followed with the correct criteria (1). Though the majority of the respondents' answers were partially incorrect (66 respondents), it is also to be noted that the participants are able to choose more than one answer which resulting in doubtful answers. With the line thickness, going from the general to the specific details of the topic, can be acknowledged that the respondents have grasp the concept of mind mapping well seeing their top two answers are the correct ones for the line thickness. Whilst their concept of the line form and doubt could be highly influenced by the habit of going straight to the answer that are top of mind but seeing the different variation of answers drive them to a state of doubt where they may have chosen two similar answers at once, hence the result has become of the above. 


\subsection{Skills gained through mind mapping}

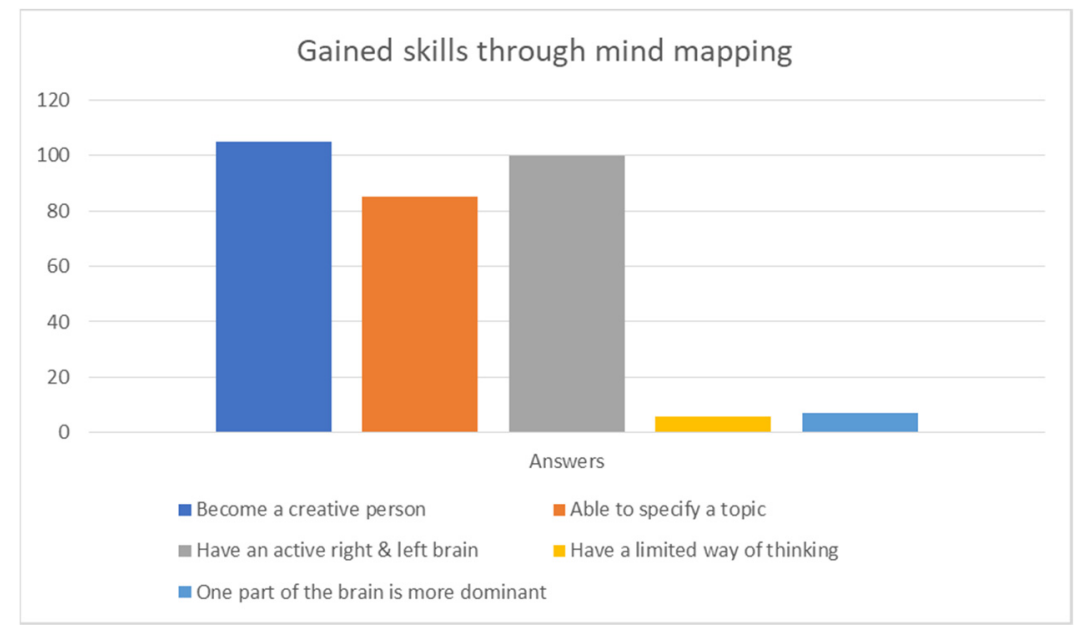

Figure 7: The skills users might gain when utilizing mind mapping

Figure 7 have highlighted the respondents understanding that mind mapping can act as a tool to improve individual skills. This result is shown by the majority that choose answer with the indications of benefiting the personnel that can utilize mind mapping in their field of focus. The participants highlight that mind mapping is able to hone useful skills such as, developing a creative mind to be able to innovate further on (105 respondents), having a balanced way of thinking from the brain perspective as to give better and more concrete understanding then able to develop ideas through it (100 respondents), and finally they have agreed that mind mapping can utilize in the way of people to specify topics regarding their readings and/or materials ( 85 respondents).

This objective of the current study was to perceive the knowledge of prospective English teachers in Indonesia regarding mind mapping. The result showed that English language educators and teacher in-training have profoundly agree of the use of mind mapping in the education process. Figure 4 has further highlights respondents' scope on the function of mind mapping, which indicates that they acknowledge the use of the tool. The respondents' understanding of mind mapping is also presented through Figures $3 \& 6$, in which they can answer the concept of the construction of mind mapping through its components. These findings matched our expectation in providing a motivating technique that further improve the English language education process.

Despite the misconception of the tools used by few of the respondents, the majority has showed statements that further supports the aims of this study. The finding on Figure 7 indicates that mind mapping can further improve an individual soft skill by activating the use of left brain to process materials and the right brain to be creative due to visualizing ideas through mind mapping. Proceeding with the individual's creative ability to improve after being able to practice drawing a mind mapping and accompanied by their intellectual ability to generate a conclusion of the topic from their general ideas. From these we have found that mind mapping can highly assist in conducting student-centered learning environment.

In turn, as these aims were to be achieved and being practiced over a period, it will suffice in providing a good work-study habit that will be implemented for our prospective teachers dwelling in English language education. As prospective teachers hopefully this work-study habit with selflearning values and induced creativity may be passed down to the learners learning from the practitioners and are able to fully improve and develop a better human resource not just in themselves but as well as the surrounding society. 


\section{Conclusion}

This study involves respondent from universities with different environment of studies in Indonesia. Despite that indication, the majority of respondents have agreed on many things. The study's findings have further supported the achievement of the objectives in conducting it. Hence, this study has shown that prospective English teachers have good knowledge on mind mapping however adding the indication that they are still lacking in complete understanding and the process of constructing mind mapping. Furthermore, this study highlights those prospective English teachers require advance practice of utilizing mind mapping in tasks they perform as it is believed to be a supporting tool during brainstorming, lesson-planning, summarizing references, outlining essays, etc. The reason for this is that the participants themselves have clearly highlighted the effective usage of mind mapping throughout this research. It is very anticipated that the tool can be fully utilized to improve not just their performance but the whole education system as well, as their knowledge will be transferred to their learners later.

\section{Funding}

This research is funded by Indonesian Ministry of Education and Culture (Kemendikbud) Director General of Higher Education (DIKTI) in 2021.

\section{Acknowledgement}

The earlier version of this paper has been presented in The International Conference on Education (ICE) 2021 in State University of Malang, Indonesia.

\section{References}

Arnon, S., \& Reichel, N. (2007). 'Who is the ideal teacher? Am I? Similarity and difference in perception of students of education regarding the qualities of a good teacher and of their own qualities as teachers'. Teachers and Teaching, 13(5), 441-464.

Biktimirov, E. N., \& Nilson, L. B. (2006). Show them the money: Using mind mapping in the introductory finance course. Journal of Financial Education, 72-86.

Borg, S. (2006). The distinctive characteristics of foreign language teachers. Language Teaching Research, 10(1), 3-31.

Buzan, Tony. (1974). Use Your Head. England: BBC Publication.

Buzan, Tony. (2012). Mind Mapping: Scientific Research and Studies. www.iMindMap.com.

Chan, Wai-ling. (2004). The Effectiveness of Using Mind Mapping Skills in Enhancing Secondary One and Secondary Four Students' Writing in a CMI School. University of Hong Kong, Masters Dissertation. http://hub.hku.hk/handle/123456789/31749?mode=full\&submit_simple=Show+full+item+record

Cheung, H. Y. (2006). The measurement of teacher effectiveness: Hong Kong primary in-service teachers. Journal of Education for Teaching, 32(4), 435-451.

Christiani, N. (2014). Reading-to-write in the classroom: The use of mind mapping as schemata and as outlining. Journal Humaniora, Sains, Pendidikan dan Pengajaran PROSPECTS, 4(2), 53-59.

Christiani, N., \& Latief, M. A. (2018). EFL learners' opportunities and problems in literacy strategy implementation. In ELT in Asia in the Digital Era: Global Citizenship and Identity (pp. 433-438). Routledge.

Demmon-Berger, D. (1986). Effective teaching: Observations from research. Arlington, VA: American Association of School Administrators (ERIC Document Reproduction Service No. ED274087).

Dev, Meenu. (2016). Constructivist approach enhances the learning: A search of reality. Journal of Education and Practice, 7(25), 59-62.

Durmus, Y. T. (2016). Effective learning environment characteristics as a requirement of constructivist curricula: Teachers' needs and school principals' views. International Journal of Instruction, 9(2), 183-198.

Elizabeth, C. L., May, C. M., \& Chee, P. K. (2008). Building a model to define the concept of teacher success in Hong Kong. Teaching and Teacher Education, 24(3), 623-634. DOI: 10.1016/j.tate.2007.09.007

Grimes, D. A., \& Schulz, K. F. (2002). Descriptive studies: what they can and cannot do. The Lancet, 359(9301), 145149. 
Hunt, B. C. (2009). Teacher effectiveness: A review of the international literature and its relevance for improving education in Latin America (Working Paper No. 43). Washington, DC: Partnership for Educational Revitalization in the Americas.

Kim, B. (2001). Social constructivism. Retrieved October 5, 2005, from http://www.coe.uga.edu/epltt/Social Constructivism.htm

Korkmaz, Ş. Ç., \& Yavuz, A. (2011). ELT student teachers' perspectives of an effective English teacher. Journal of Theory and Practice in Education, 7(2), 207-229.

Krashen, S. D. (1984). Writing: Research, Theory, and Applications. Oxford: Pergamon.

Kulekci, G.. (2018). Identifying the perceptions of prospective English language teachers on characteristics of effective teachers: Who is the ideal teacher? Novitas-ROYAL (Research on Youth and Language) Journal, 12(1), 1-15.

Muldyagin, D. H. (2018). The Correlation between the Interest in Practicing English Conversation and Speaking Fluency of English Department Students of Pasundan University. Institutional Repositories E Scientific Journals of Universitas Pasundan.

Parikh, N. D. (2016). Effectiveness of teaching through mind mapping technique. The International Journal of Indian Psychology, 3(3), 148-156.

Porter, A., \& Brophy, J. (1988). Synthesis of research on good teaching: Insights from the work of the Institute of Research on Teaching. Educational Leadership, 45(8), 74-85.

Sarita, P. (2017). Constructivism: A new paradigm in teaching and learning. International Journal of Academic Research and Development, 2(4), 183-186.

Sluijsmans, D. M. A., \& Strijbos, J. W. (2010). Flexible peer-assessment formats to acknowledge individual contributions during (web-based) collaborative learning. In B. Ertl (Ed.), E-Collaborative knowledge construction: Learning from computer supported and virtual environments (pp.139-161). Retrieved September 17, 2011 from http://issuu.com/daharkedjosappiring/docs/e_collaborative_knowledge_construction

Watson, R. (2015). Quantitative research. Scholarly Journal, 29 (31), 44. DOI:10.7748/ns.29.31.44.e8681

Witcher, A., Onwuegbuzie, A., \& Minor, L. (2001). Characteristics of effective teachers: Perceptions of preservice teachers. Research in the School, 8, 45-57. 